\title{
Effect of surgical preparation and arterialization on vasomotion of human saphenous vein
}

To gain an insight into venous physiologic adaptation to arterialization, this study examined the effects of thromboxane, 5-hydroxytryptamine, endothelin, leukotriene $C_{4}$, and norepinephrine on isolated segments of native and distended human saphenous vein, short-term (up to 1 year) grafts, and long-term ( 1 to 10 year) grafts. The mean maximum constrictor responses, expressed as percentage of maximum potassium depolarization, were as follows: thromboxane analog U46619: native vein $147.0 \% \pm$ $10.5 \%$, distended vein $251.2 \% \pm 29.1 \%$, short-term graft $174.6 \% \pm 33.8 \%$, long-term graft $220.9 \% \pm 21.7 \%$; 5-hydroxytryptamine: native vein $115.6 \% \pm 6.1 \%$, distended vein $129.9 \% \pm$ $13.3 \%$, short-term graft $80.0 \% \pm 15.0 \%$, long-term graft $95.1 \% \pm 12.1 \%$; endothelin-1: native vein $126.5 \% \pm 22.1 \%$, distended vein $138.1 \% \pm 24.7 \%$, short-term graft $120.7 \% \pm 43.3 \%$, long-term graft $171.4 \% \pm 26.0 \%$; leukotriene $C_{4}$; native vein $49.9 \% \pm 8.7 \%$, distended vein $78.9 \% \pm 11.8 \%$, short-term graft $90.8 \% \pm 39.1 \%$, long-term graft $7.4 \% \pm 5.0 \%$; and norepinephrine: native vein $127.0 \% \pm 9.3 \%$, distended vein $155.0 \% \pm 17.8 \%$, short-term graft $61.6 \% \pm 11.3 \%$, long-term graft $80.1 \% \pm 7.7 \%$. The vasoconstriction elicited by each agonist, in absolute terms (in millinewtons), diminished with age of graft. We conclude that surgical treatment of saphenous vein immediately renders it more responsive to $\mathrm{U} 46619$, norepinephrine, and leukotriene $\mathrm{C}_{4}$. An agonist-specific profile of response was evident up to 10 years after operation, which may affect myocardial blood supply when luminal bore is diminished by vein graft disease. (J THORAC CardIOvasc Surg 1994;107:699-706)

Gregory S. O'Neil, PhD, Adrian H. Chester, PhD, Catherine J. Schyns, Samad Tadjkarimi, MD, Julie A. A. Borland, BN, and Magdi H. Yacoub, FRCS, Harefield, Middlesex, United Kingdom

$\mathrm{U}_{\mathrm{n}}$ ntil recently, vein bypass grafts have been thought to function as passive conduits delivering blood to the myocardium. However, evidence is accumulating that these grafts possess the capacity to alter their lumen diameter, which may have an important influence on their performance in terms of both altering flow and affecting early and long-term patency. The factors involved in the control of vasomotion of vein grafts have not been adequately examined.

Many studies, relying on the use of native (undistended) saphenous vein, have addressed the underlying mechanisms of poor vein graft performance. ${ }^{1}$ Biologically,

From the Department of Surgery, National Heart and Lung Institute, Harefield Hospital, Harefield, Middlesex, United Kingdom.

Received for publication June 7, 1993.

Accepted for publication Sept. 24, 1993.

Address for reprints: Magdi H. Yacoub, FRCS, Department of Surgery, National Heart and Lung Institute, Harefield Hospital, Harefield, Middlesex, UB9 6JH, United Kingdom.

Copyright $\odot 1994$ by Mosby-Year Book, Inc.

$0022-5223 / 94 \$ 3.00+0 \quad \mathbf{1 2} / \mathbf{1} / \mathbf{5 1 7 7 8}$ these studies have focused on damaged or impaired vasodilator function ${ }^{2-4}$ and inadequate protection against vasoconstrictor influences ${ }^{5}$; histologically, the comparatively large size and muscular nature of the vein (together with postdistention flaccidity) is thought to be limiting in its adaptation to arterial flow subsequent to revascularization, and it is in response to these increases in transmural pressure and pulsatility (in addition to vascular injury ${ }^{6}$ ) that smooth muscle cell proliferation probably occurs. 7,8

Although experiments with nongrafted human saphenous vein can provide important information as to the mechanism of vein graft performance, there is a dearth of information regarding the physiologic processes that occur in human saphenous vein engrafted into the arterial circulation. Preserved endothelium-dependent and endothelium-independent dilator responses have been reported up to 12 years after operation, which correlates with the degree of smooth muscle proliferation as opposed to age of the graft, ${ }^{9}$ whereas studies in animals have demonstrated altered short-term vasoconstrictor ${ }^{10,11}$ and vasodilatory ${ }^{12}$ vascular responses. 
The purpose of this study was to examine the effect of vasoconstrictor substances encountered either endogenously (thromboxane, 5-hydroxytryptamine, endothelin, and leukotriene $\mathrm{C}_{4}$ ) or during perioperative and postoperative drug therapy (norepinephrine) on undistended (native) and distended human saphenous vein, as well as short-term (up to 1 year) and long-term ( 1 to 10 year) vein grafts.

\section{Methods}

Harvesting of tissue. Human saphenous vein was obtained from three sources. (1) Undistended (native) vein, surplus to requirement, was procured before distention at coronary artery bypass graft operations. After isolation, the vein was immediately placed in cold, modified Tyrode's solution of the following composition (in millimoles per liter): sodium chloride 136.9, sodium hydrogen carbonate 11.9 , potassium chloride 2.7 , sodium dihydrogen orthophosphate 0.4 , magnesium chloride 2.5 , glucose 11.1, and disodium ethylenediaminetetraacetic acid 0.04 and cut into 3 to $5 \mathrm{~mm}$ segments within 30 minutes. In this study, 78 segments were used from 10 patients with ages in the range of 56 to 73 years, mean 65 years. (2) Vein, also surplus to requirement at bypass grafting, was obtained after uncontrolled surgical distention with heperanized saline and placed in modified Tyrode's solution: 64 segments were used from a different 10 patients with ages in the range of 56 to 73 years, mean 64.1 years. (3) Patent vein grafts were harvested from patients undergoing cardiac transplantation for severe myocardial dysfunction. Only grafts with a clearly patent lumen and no clots or ulcerating plaques were used. The grafts were excised from hearts immediately on explantation. After transportation to the laboratory in cold Tyrode's solution, the grafts were cleaned of surrounding connective tissue and cut into segments. These vessels were categorized into short-term grafts (graft age in the range of 8 to 12 months, mean $10.0 \pm 0.84$ months; patient age range 39 to 56 years, mean $47.4 \pm 3.12$ years; 36 segments used from five patients) and long-term grafts (graft age in the range of 8 to 11 years, mean $9.4 \pm 0.6$ years; patient age range 58 to 65 years, mean $62.4 \pm 1.21$ years; 30 segments used from five patients).

Functional studies. Saphenous vein segments from all groups of tissue were treated in an identical manner: segments were placed in $5 \mathrm{ml}$ organ baths that contained modified Tyrode's solution and were mounted on two L-shaped intraluminal hooks. The baths were gassed continuously with $95 \%$ oxygen and $5 \%$ carbon dioxide and maintained at $37^{\circ} \mathrm{C}$. After application of $60 \mathrm{mN}$ tension, the segments were allowed to relax, over a period of 90 minutes, to a stable baseline. Potassium chloride was administered to assess tissue viability and provide standard contractile responses against which receptormediated phenomena could be examined.

The following vasoconstrictors were then added cumulatively in one-half log doses: norepinephrine $\left(10^{-9}\right.$ to $\left.10^{-4} \mathrm{~mol} / \mathrm{L}\right)$, thromboxane analog $\mathrm{U} 46619\left(10^{-9}\right.$. to $\left.10^{-5} \mathrm{~mol} / \mathrm{L}\right), 5$-hydroxytryptamine $\left(10^{-9}\right.$ to $\left.10^{-5} \mathrm{~mol} / \mathrm{L}\right)$, endothelin- $1\left(10^{-9}\right.$ to $10^{-7}$ $\mathrm{mol} / \mathrm{L})$, and leukotriene $\mathrm{C}_{4}\left(10^{-9}\right.$ to $\left.10^{-7} \mathrm{~mol} / \mathrm{L}\right)$. Each dose was allowed to effect its maximum response and only one constrictor was used per vessel segment.

Data analysis. Responses were expressed both as percentage of maximum contraction elicited by potassium chloride and as absolute response in millinewtons. Data are reported as mean maximum responses \pm standard error of the mean. In some of the groups of data, the $n$ value (number of segments) was small, so it was not assumed that the data were normally distributed. Therefore the Mann-Whitney $U$ test was used for comparison of mean maximum responses and significance assigned at $p<0.05$.

Morphologic studies. So that the degree of myointimal proliferation, changes in gross morphologic state, and endothelium integrity could be visualized, representative segments of undistended and distended vein and patent short- and long-term grafts were fixed in formalin, wax-embedded, and sectioned for histologic staining. The endothelium was selectively stained with antibody against factor VIII; van Giesen stain was used to counterstain underlying tissues.

\section{Results}

Vasoconstrictor responses. The patients in this study form a complex group, with many combinations of drug therapy regimens. We could detect no effect of any such combination on subsequent organ bath experiments.

Potassium chloride. Segments of native (undistended) saphenous vein constricted significantly $(p<0.05)$ more to potassium chloride than any of the other three groups of tissue, with a mean maximum response of $43.4 \pm 3.4$ $\mathrm{mN}$ ( $n=78$ segments, 10 patients) compared with 22.0 $\pm 2.8 \mathrm{mN}$ ( $n=64$ segments, 10 patients), $23.2 \pm 3.5$ $\mathrm{mN}(n=36$ segments, 5 patients), and $10.0 \pm 1.1 \mathrm{mN}$ ( $n=30$ segments, 5 patients) in distended vein, shortterm venous grafts, and long-term venous grafts, respectively. There was no significant difference between the mean potassium response in distended and short-term vein; however, the smallest mean maximum response was recorded in long-term venous graft, and this was significantly different $(p<0.05)$ from that in all other groups (Fig. 1).

U46619. The thromboxane mimetic U46619 produced powerful dose-dependent constrictions in all segments tested (Fig. 2). When expressed as percentage of the potassium chloride response, the most efficacious responses were in distended and long-term venous graft with mean maximum responses of $251.2 \% \pm 29.1 \%(n=15$ segments, 8 patients $)$ and $220.9 \% \pm 21.7 \%(n=7$ segments, 3 patients), respectively. These were significantly different from the response of native vein $(147.0 \% \pm$ $10.5 \%, n=17,8$ patients, $p<0.02$ ). When absolute responses (in millinewtons) were examined, this trend was partially reversed, in that native vein produced the greatest mean maximum response $(77.5 \pm 9.4 \mathrm{mN})$ and this was significantly higher than that in the other groups of tissue $(p<0.02)$. Table I indicates that the response in long-term venous grafts was only $19.5 \pm 3.6 \mathrm{mN}$, which indicates that the absolute response decreases with the increased age of the tissue.

5-Hydroxytryptamine. Dose-dependent constrictions to 5-hydroxytryptamine were seen. As assessed against 


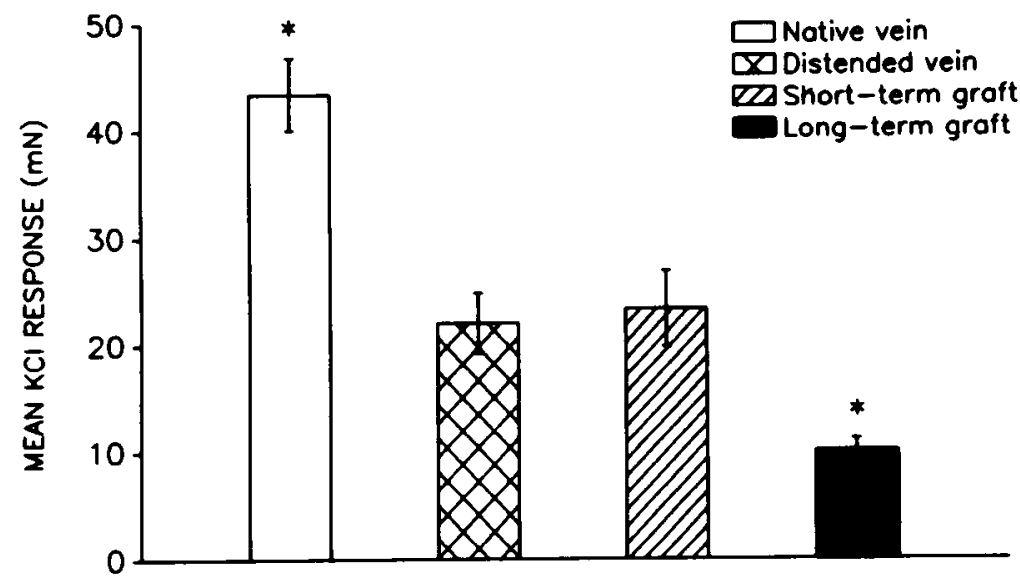

Fig. 1. Mean maximum potassium chloride responses (millinewtons) in human native saphenous vein $(n=78,10$ patients), distended saphenous vein ( $n=64,10$ patients), short-term venous graft ( $n=36,5$ patients), and long-term venous graft ( $n=30,5$ patients). All data expressed as means \pm standard error of mean; $n=$ number of segments. Asterisk $(p<0.02)$ represents significant difference from all other groups of tissue.

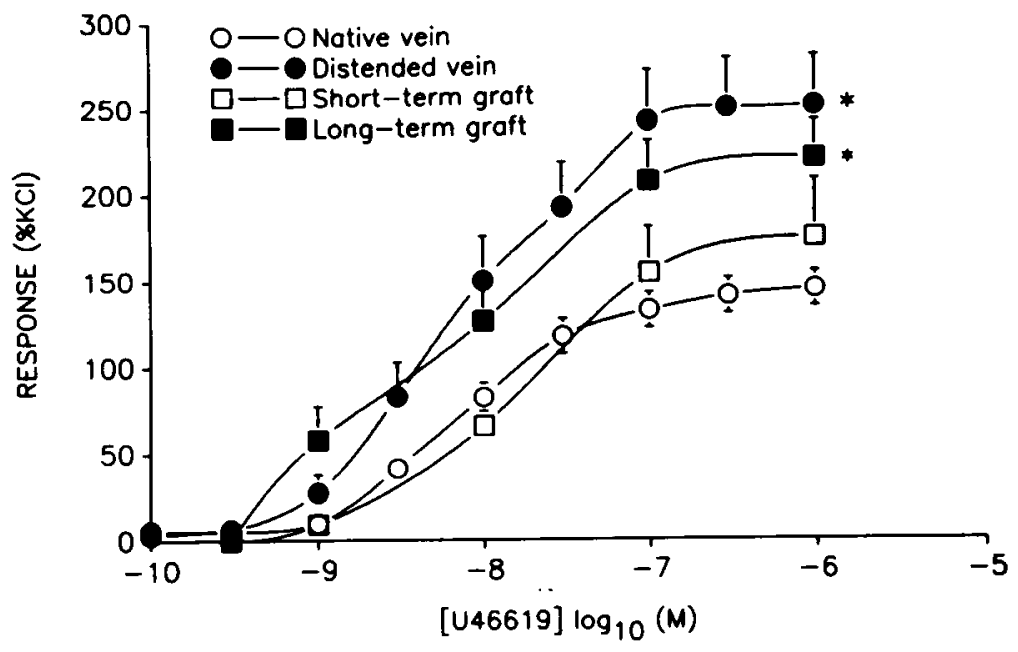

Fig. 2. Dose-related vasoconstriction (expressed as percent of maximum potassium chloride depolarization) in response to thromboxane analog U46619 in human native saphenous vein ( $n=17,8$ patients), distended saphenous vein ( $n=15,8$ patients), short-term venous graft ( $n=10,5$ patients), and long-term venous graft ( $n=7,3$ patients). All data expressed as mean \pm standard error of mean; $n=$ number of segments. Asterisk $(p<0.02)$ represents significant difference compared with native vein.

the potassium chloride response, the responses were as follows: native vein: $115.6 \% \pm 6.1 \%, n=12,6$ patients; distended vein: $129.9 \% \pm 13.1 \%, n=12,6$ patients; short-term venous graft: $80.0 \% \pm 15.0 \%, n=10,5$ patients; long-term venous graft: $95.1 \% \pm 12.1 \%, n=6$, 3 patients. These differences were not significantly different. When absolute values (in millinewtons) were examined (Table I), the largest mean maximum was associated with native vein $(51.1 \pm 5.7 \mathrm{mN})$ with all other groups of venous tissue responding significantly less $(p<0.05)$. These absolute responses fell to a minimum mean of $11.1 \pm 5.74 \mathrm{mN}$ in the 10-year grafts.

Endothelin-1. Endothelin-1 constricted all vein segments. When compared with maximum potassium chloride constrictions, there was a significantly $(p<0.05)$ enhanced maximum response in long-term graft tissue: native vein: $126.5 \% \pm 22.1 \%, n=16,7$ patients; distended vein: $138.1 \% \pm 24.7 \%, n=15,7$ patients; short-term 
Table I. Mean maximum absolute responses (millinewtons) of human saphenous vein (native, distended, and grafted) to U46619, 5-hydroxytryptamine, endothelin-1, leukotriene $C_{4}$, and norepinephrine

\begin{tabular}{lccccc}
\hline & & \multicolumn{4}{c}{$E_{\max }$} \\
\cline { 2 - 6 } & U46619 & $5-H T$ & $E T-I$ & LTC4 & NE \\
\hline Native vein & $77.5 \pm 9.4$ & $51.1 \pm 5.7$ & $38.0 \pm 6.1$ & $17.4 \pm 2.7$ & $41.2 \pm 4.5$ \\
Distended vein & $n=17(8)$ & $n=12(6)$ & $n=16(7)$ & $n=15(5)$ & $n=18(6)$ \\
& $28.4 \pm 3.9$ & $28.7 \pm 7.9$ & $21.0 \pm 3.9$ & $17.9 \pm 4.0$ & $38.7 \pm 14.4$ \\
Short-term* & $n=15(8)$ & $n=12(6)$ & $n=15(7)$ & $n=11(5)$ & $n=11(6)$ \\
Long-term* & $24.7 \pm 6.3$ & $16.7 \pm 4.7$ & $15.6 \pm 14.7$ & $11.4 \pm 3.4$ & $17.2 \pm 4.0$ \\
& $n=10(5)$ & $n=10(5)$ & $n=3(2)$ & $n=5(2)$ & $n=8(4)$ \\
& $19.5 \pm 3.6$ & $11.1 \pm 2.3$ & $13.0 \pm 3.2$ & $1.4 \pm 1.0$ & $7.0 \pm 1.4$ \\
& $n=7(3)$ & $n=6(3)$ & $n=7(3)$ & $n=4(2)$ & $n=6(3)$ \\
\hline
\end{tabular}

Data (in millinewtons) expressed as means plus or minus standard error of mean. $n$ indicates number of segments; parenthesis denotes number of patients. $E_{\text {max }}$ Mean maximum absolute responses; 5 - $H T$, 5-hydroxytryptamine; $E T-1$, endothelin-1; $L T C_{4}$, leukotriene $\mathrm{C}_{4} ; N E$, norepinephrine.

*Short-term graft $=8$ to 12 months; long-term graft $=1$ to 11 years.

venous graft: $120.7 \% \pm 43.4 \%, n=3,2$ patients; longterm venous graft: $171.4 \% \pm 26.0 \%, n=7,3$ patients: However, the mean maximum absolute values (in millinewtons) (Table I) again reflected the origin of the vein, ranging from $38.0 \pm 6.1 \mathrm{mN}$ in native vein to $13.0 \pm 3.2$ $\mathrm{mN}$ in long-term venous graft; statistical comparisons of these extremes reached significance $(p<0.02)$.

Leukotriene $C_{4}$. Leukotriene $\mathrm{C}_{4}$ induced dose-dependent constrictions in all groups of tissue (Fig. 3). The mean maximum responses obtained with segments from long-term venous grafts were significantly $(p<0.02)$ diminished as compared with those in native vein. In addition, the response in distended vein was significantly $(p<0.05)$ enhanced. The constrictions were as follows: native vein $49.9 \% \pm 8.7 \%, n=15,5$ patients; distended vein $78.9 \% \pm 11.8 \%, n=11,5$ patients; short-term venous graft $90.8 \% \pm 39.1 \%, n=5,2$ patients; and longterm venous graft $7.4 \% \pm 5.0 \%, n=4,2$ patients. In terms of absolute responses (in millinewtons), again the mean maximum values decreased with the age of the graft (Table I).

Norepinephrine. Vein segments from all groups of tissue responded to norepinephrine in a dose-dependent manner (Fig. 4). As seen in the figure, the engrafted material responded less efficaciously as assessed against the potassium chloride response, compared with native and distended vein $(p<0.02)$. The mean maximum responses were as follows: native vein $127.0 \% \pm 9.3 \%$, $n=18,6$ patients; distended vein $155.0 \% \pm 17.8 \%$, $n=11,6$ patients; short-term venous graft $61.6 \% \pm$ $11.3 \%, n=8,4$ patients; and long-term venous graft $80.1 \% \pm 7.7 \%, n=6,3$ patients. In addition, the response of distended vein was significantly higher than that of native vein $(p<0.02)$. As described for the constrictors U46619 and 5-hydroxytryptamine, the absolute responses (in millinewtons) reflected the status and age of the preparation (Table I) with a largest mean maximum response in native vein of $41.2 \pm 4.5 \mathrm{mN}$. This dropped to $7.0 \pm 1.4 \mathrm{mN}$ in the long-term graft tissue and differences were significant $(p<0.05)$ when nongrafted and engrafted vessels were compared.

Morphologic studies. Representative sections of native and distended saphenous vein and short- and longterm venous graft tissue are shown in Fig. 5, $a$ to $d$. In native vein (Fig. $5, a$ ) the typically invaginated vessel wall was preserved and appeared to be covered with a complete and intact endothelium; there was no sign of myointimal proliferation. The process of vein distention predictably smoothed out the vessel wall invaginations (Fig. 5,b), but also resulted in occasional disruption and general flaking of the endothelium. The appearance of sections of shortterm vein graft (Fig. 5, c) resembled that of native vein in that the vessel wall again appeared invaginated and was covered with an apparently intact endothelium; however, focal areas of subintimal collagen proliferation were observed. Long-term vein graft sections ( Fig. 5, d) showed severe myointimal fibromuscular proliferation associated with a diminished lumen diameter.

\section{Discussion}

This study demonstrated that the process of surgical preparation and arterialization has a marked and varied effect on the response of the human saphenous vein to vasopressor substances that could be expected to be encountered either as endogenous mediators or as a result of perioperative or postoperative drug therapy. The age of a graft was found to be inversely related to absolute contractility of vessel segments. However, by normalizing the data to maximum potassium response, we found that during the process of vein graft disease, receptor preservation is agonist-specific, revealing a putative area of selective pharmacologic intervention.

Absolute responses. After saphenous vein grafting, there are progressive changes in the vessel wall that result 


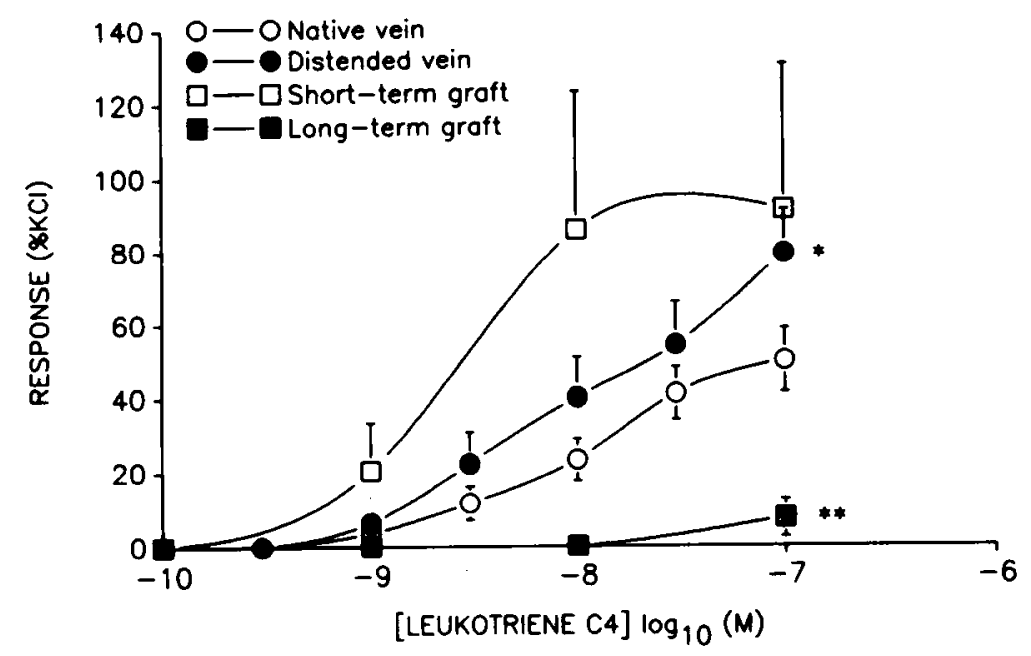

Fig. 3. Dose-related vasoconstriction (expressed as percent of maximum potassium chloride depolarization) in response to leukotriene $\mathrm{C}_{4}$ in human native saphenous vein $(n=15,5$ patients), distended saphenous vein $(n=11$, 5 patients), short-term venous graft $(n=5,2$ patients), and long-term venous graft ( $n=4,2$ patients). All data expressed as mean \pm standard error of mean; $n=$ number of segments. Single asterisk $(p<0.05)$ and double asterisks $(p<0.02)$ represent significant difference compared with native vein.

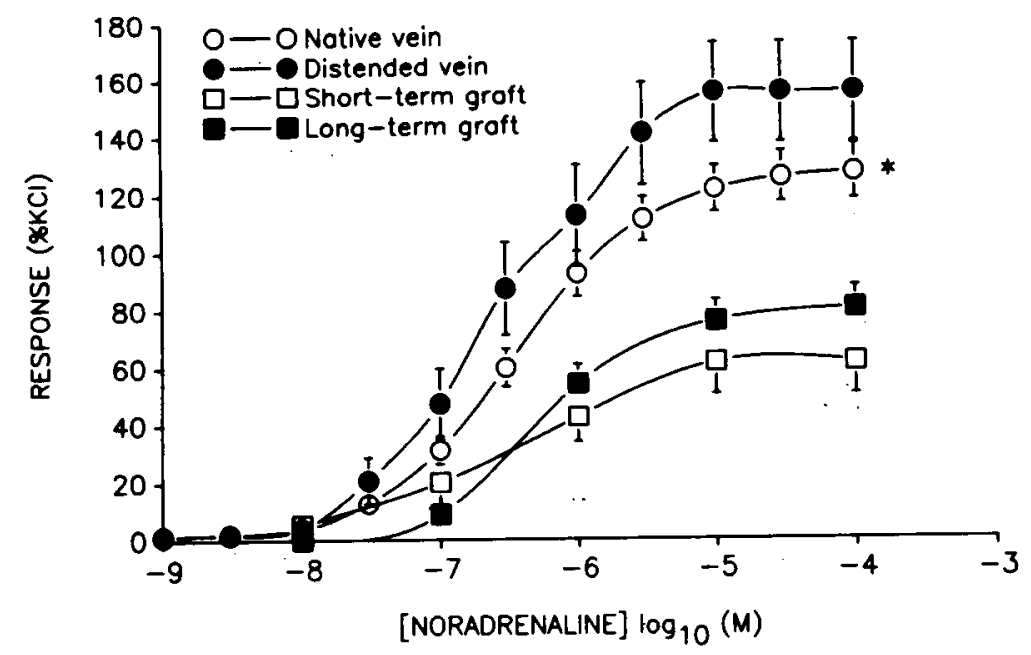

Fig. 4. Dose-related vasoconstriction (expressed as percent of maximum potassium chloride depolarization) in response to norepinephrine in human native saphenous vein $(n=18,6$ patients), distended saphenous vein $(n=11$, 6 patients), short-term venous graft ( $n=8,4$ patients), and long-term venous graft ( $n=6,3$ patients). All data expressed as mean \pm standard error of mean; $n=$ number of segments. Asterisk $(p<0.02)$ represents significant difference between native vein and all other groups of tissue.

in intimal proliferation followed by varying degrees of atheromatous changes. ${ }^{13-16}$ This could influence the vasomotor responses of the vessel through a variety of mechanisms. In our experiments, the absolute response in millinewtons decreased on vein distention irrespective of agonist used. Early diminution of absolute response has also been described in dog saphenous vein in which max- imal absolute response was significantly decreased in 1-week grafted veins responding to phenylephrine, histamine, and serotonin. ${ }^{10}$ Our study confirms that, in human beings, this decrease therefore is not due to disease processes but probably reflects metabolic/structural alterations resulting from implantation. The absolute response also diminished according to the age of the graft, and this 

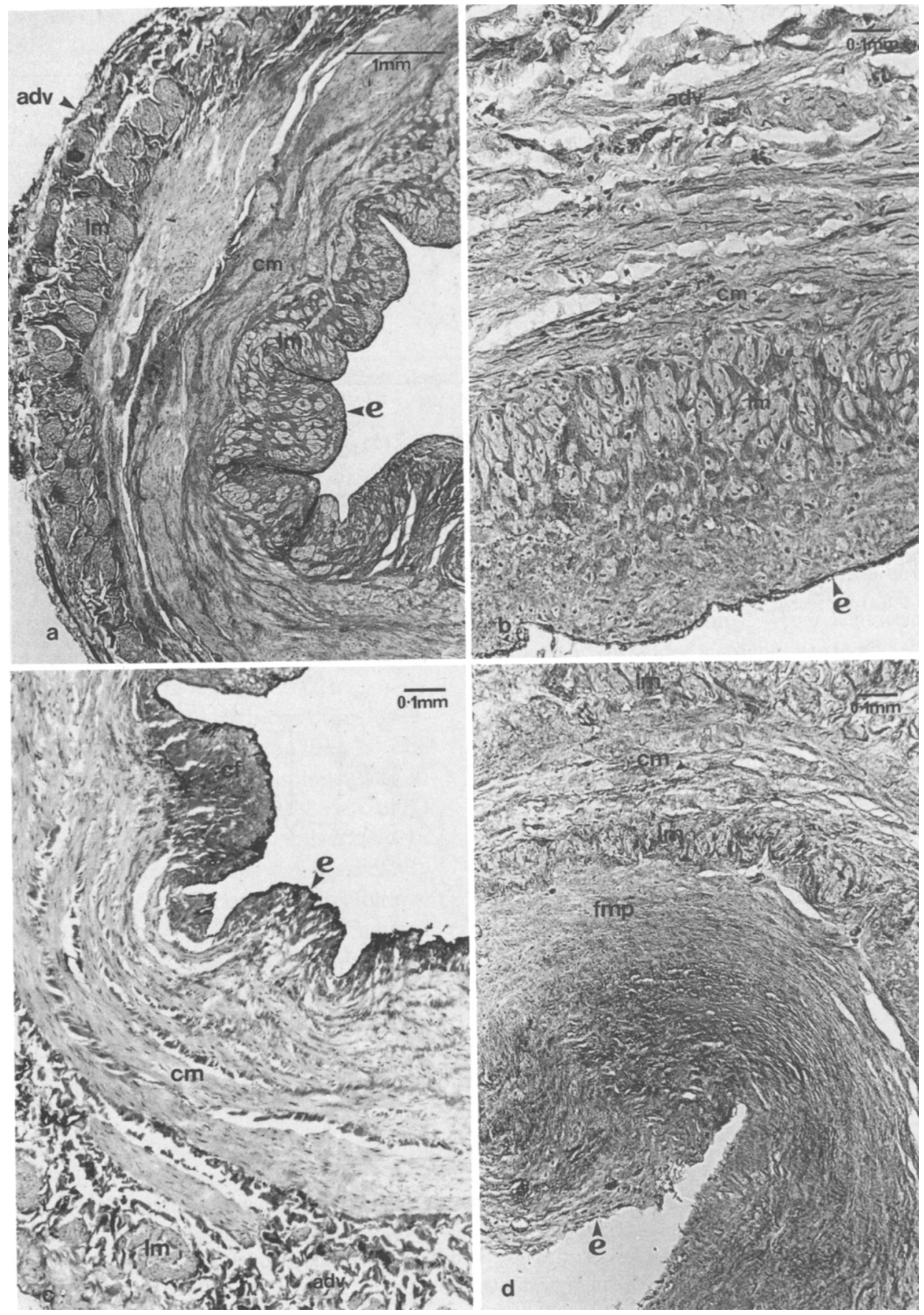

Fig. 5. Histologic appearance of (a) native saphenous vein (original magnification $\times 25$ ), (b) distended saphenous vein (original magnification $\times 100$ ), (c) short-term 1-year graft (original magnification $\times 100$ ), and (d) long-term 10-year graft (original magnification $\times 100$ ). Factor VIII and van Giesen stain, $6 \mu \mathrm{m}$ formalin-fixed paraffin sections. $a d \nu$, Adventitia, $c m$, circular muscle, $c t$, collagenous thickening, $e$, endothelium, $f m p$, fibromuscular proliferation, $l m$, longitudinal muscle.

is probably due to venous stiffening and the loss of mechanical contractile ability. These findings are in contrast to those of a previous report that documented the hyperactivity of severely diseased human saphenous vein grafts in response to potassium chloride and prostaglandin $F_{2 \alpha}$ as compared with moderately diseased vein grafts ${ }^{9}$; this discrepancy is difficult to explain, but in the present study the degree of luminal occlusion in the 
severely diseased group of tissue was greater and the blunted responses may be largely a reflection of loss of mechanical contractile ability.

Responses as assessed against potassium chloride. The receptor-mediated control of short- and long-term vein graft vasoconstriction has not previously been studied. In our study, thromboxane, 5-hydroxytryptamine, endothelin-1, leukotriene $\mathrm{C}_{4}$, and norepinephrine produced dose-dependent constrictions in native unprepared saphenous vein segments of a magnitude and potency comparable with those cited in previous reports. ${ }^{5,17-20}$ After vein distention, however, the doseresponse curves for U46619, 5-hydroxytryptamine, leukotriene $\mathrm{C}_{4}$, and norepinephrine were always increased above that seen in native vein, and this was statistically significant in the case of U46619, norepinephrine, and leukotriene $\mathrm{C}_{4}$. These early alterations in vascular reactivity are presumably due to endothelial damage and removal of vasodilatory effects of endogenous dilators such as endothelium-derived relaxing factor ${ }^{2,3}$ and prostacyclin $^{21,22}$ combined with further damage to the endothelium and/or enhancement of vascular reactivity caused by perioperative storage. In addition, endothelium disruption may afford increased access to contractionmediating receptors on underlying smooth muscle. This immediate, short-term enhancement of vascular reactivity has recently been reported in dog saphenous veins in which receptor-mediated constriction to phenylephrine, histamine, and 5-hydroxytryptamine was increased 1 week after implantation into the carotid artery. ${ }^{10}$ Thromboxane maintained an enhanced effect in long-term grafts, which indicated that relative to the potassium chloride response receptor function had been preserved despite gross fibromuscular proliferation. There was uniformity in the endothelin response, whereas 5-hydroxytryptamine, leukotriene $\mathrm{C}_{4}$, and norepinephrine produced responses indicative of loss of receptor function, and this could be due to a number of reasons: (1) reduction in number of functional receptors as a result of plaque development, (2) dysfunction of metabolic processes subsequent to receptor activation, and (3) opposing endothelial dilatory mechanisms after regrowth of endothelium. ${ }^{11}$ Our results show that a specific profile of receptor-mediated response was retained that differed between agonists. This could play an important role in the pathogenesis of vein graft occlusion and contribute to the regulation of blood flow through the conduit.

Pathophysiologic implications. In the immediate phase after cardiopulmonary bypass, thromboxane, norepinephrine, and leukotriene $\mathrm{C}_{4}$ may crucially affect graft lumen diameter. Thromboxane, whose levels are elevated in patients with ischemic heart disease, ${ }^{23,24}$ will be released from aggregating platelets after any damage to the endothelium and may constrict the graft; preservation of thromboxane receptor function in long-term grafts indicates that this could be an ongoing event. Norepinephrine, commonly administered postoperatively to stabilize the hemodynamic condition of the patient, ${ }^{25}$ may produce detrimental constriction after distention of the vein graft. Adhesion and activation of leukocytes occurs after exposure of subendothelium and collagen subsequent to endothelial damage on preparation and insertion of saphenous vein grafts. ${ }^{26}$ Leukotrienes will then be released ${ }^{27}$ and, as this study demonstrates, may constrict the graft in the early stages; furthermore leukotriene levels have also been found to be elevated in certain cardiovascular disorders. ${ }^{28}$

The actions of 5-hydroxytryptamine and endothelin are less likely to have a significant effect on blood flow through vein grafts. However, endothelin did produce a significantly enhanced response in long-term grafts and its ability to interact with 5-hydroxytryptamine and norepinephrine, ${ }^{29}$ as well as its smooth muscle mitogenic effects, ${ }^{30}$ may be more important. Similarly 5 -hydroxytryptamine, a role for which has been implied in vasospasm after its release from aggregating platelets, ${ }^{31}$ though only producing a weak increase in constrictor response in this study, may synergize with thromboxane ${ }^{32}$ to reduce graft flow.

These data demonstrate that in engrafted vein, the preservation and activity of receptors compete against the effects of vascular stiffness, indicating retention of dynamic control of vascular reactivity even in diseased vein grafts. This profile of response is agonist-specific and could be amenable to pharmacologic interventions to improve blood flow to the myocardium.

We express our gratitude to theater staff at The Royal Brompton and National Heart Hospital and Harefield Hospital for their assistance in harvesting the tissue. Also, we thank the Mount Vernon Histopathology Department, in particular Jane Archer.

\section{REFERENCES}

1. Luscher TF. Vascular biology of coronary bypass grafts. Curr Opin Cardiol 1991;6:868-76.

2. Angelini GD, Christie MI, Bryan AJ, Lewis MJ. Surgical preparation impairs release of endothelium-derived relaxing factor from human saphenous vein. Ann Thorac Surg 1989;48:417-20.

3. Luscher TF, Diederich D, Siebenmann R, et al. Difference between endothelium-dependent relaxations in arterial and venous coronary bypass grafts. $N$ Engl J Med 1988; 319:462-7.

4. Lehmann KH, von Segesser L, Muller-Glauser W, et al. Internal mammary coronary artery grafts: is their superiority also due to a basically intact endothelium? Thorac Cardiovasc Surg 1989;37:187-9.

5. Yang Z, Diederich D, Schneider K, et al. Endothelium-de- 
rived relaxing factor and protection against contractions induced by histamine and serotonin in the human internal mammary artery and in the saphenous vein. Circulation 1989;80:1041-8.

6. Lawrie GM, Weilbacher DE, Henry PD. Endothelium-dependent relaxation in human saphenous vein grafts. J THORAC CARDIOVASC SURG 1990;100:612-20.

7. Loop FD, Lytle BW, Cosgrove DM. Influence of the internal mammary artery graft on 10-year survival and other cardiac events. N Engl J Med 1986;314:1-6.

8. Predel H-G, Yang Z, von Segesser L, Turina M, Buhler F, Luscher TF. Implications of pulsatile stretch on growth of saphenous vein and mammary artery smooth muscle. Lancet 1992;340:878-9.

9. Ku DD, Caulfield JB, Kirklin JK. Endothelium-dependent responses in long-term human coronary bypass grafts. Circulation 1991;83:402-11.

10. Soliman AS, Tackett RL. Early alterations in vascular reactivity of autogenous saphenous vein grafts. Coronary Artery Dis 1992;3:523-7.

11. Seidel CL, Lewis RM, Bowers R, et al. Adaptation of canine saphenous vein to grafting. correlation of contractility and contractile protein content. Circ Res 1984;55: 102-9.

12. Miller VM, Reigal MM, Hollier LH, Vanhoutte PM. Endothelium-dependent responses in autogenous femoral vein grafted into the arterial circulation of the dog. $\mathrm{J}$ Clin Invest 1987;80:1350-7.

13. Hofer H, Mihatsch MJ, Guggenheim R, Amsler B, Harse $\mathrm{J}$, Graedel E. Morphologic studies in saphenous vein grafts for aorto-coronary bypass surgery-Part 1. Morphology of the graft using ordinary surgical preparation techniques. Thorac Cardiovasc Surg 1981;29:32-40.

14. Lawrie GM, Lie JT, Morris GC Jr, Beazley HL. Vein graft patency and intimal proliferation after coronary bypass: early and long-term angiopathologic correlations. Am J Cardiol 1976;38:856-62.

15. Lie JT, Lawrie GM, Morris GC Jr. Aortocoronary bypass saphenous vein graft atherosclerosis: anatomic study of 99 vein grafts from normal and hyperlipoproteinemic patients up to 75 months postoperatively. Am J Cardiol 1977; 40:906-14.

16. Grondin CM, Campeau L, Lesperance J, Enjalbert M, Bourassa MG. Comparison of late changes in internal mammary artery and saphenous vein grafts in two consecutive series of patients 10 years after operation. Circulation 1984;70:I208-12.

17. Chester AH, Bodelsson M, Arneklo-Nobin B, Tadjkarimi $\mathrm{S}$, Tornebrandt K, Yacoub MH. Characterisation of 5-HT receptors in the human saphenous vein: implications for patency of bypass grafts. J Appl Cardiol 1990;5:51-9.

18. Luscher TF, Yang Z, Tschudi M, et al. Interaction between endothelin-1 and endothelium-derived relaxing factor in human arteries and veins. Circ Res 1990;66:1088-94.

19. Allen SP, Chester AH, Piper PJ, et al. Effects of leukot- rienes $\mathrm{C}_{4}$ and $\mathrm{D}_{4}$ on human isolated saphenous veíns. $\mathrm{Br} \mathrm{J}$ Clin Pharmacol 1992;34:409-14.

20. Weinstein JS, Grossman W, Weintraub RM, Thurer RL, Johnson RG, Morgan KG. Differences in alpha-adrenergic responsiveness between human internal mammary arteries and saphenous veins. Circulation 1989;79:1264-70.

21. Radomski MW, Palmer RMJ, Moncada S. The antiaggregating properties of vascular endothelium: interactions between prostacyclin and nitric oxide. $\mathrm{Br} \mathrm{J}$ Pharmacol 1987;92:639-46.

22. Chaikhouni A, Crawford FA, Kochel PJ, Olanoff LS, Halushka PV. Human internal mammary artery produces more prostacyclin than saphenous vein. J THORAC CARDIOVASC SURG 1986;92:88-91.

23. Coker SJ, Parratt JR, Ledingham I, Zeitlin IJ. Thromboxane and prostacyclin release from ischaemic myocardium in relation to arrhythmias. Nature 1981;291:323-4.

24. Tada M, Kuzuy $T$, Inoue $M$, et al. Elevation of thromboxane $B_{2}$ levels in patients with classic and variant angina pectoris. Circulation 1981;64:1107-15.

25. DiNardo JA, Bert A, Schwartz MJ, Johnson RG, Thurer RL, Weintraub RM. Effects of vasoactive drugs on flows through left internal mammary artery and saphenous vein grafts in man. J THORAC CARDIOVASC SURG 1991;102: 730-5.

26. Angelini GD, Bryan AJ, Williams HMJ, Morgan R, Newby AC. Distention promotes platelet and leukocyte adhesion and reduces short-term patency in pig arteriovenous bypass grafts. J THORAC CARDIOvaSC SuRG 1990; 99:433-9.

27. Takemura R, Werb Z. Secretory products of macrophages and their physiological functions. Am J Physiol 1984; 246:C1-9.

28. Carry M, Korley V, Willerson JT, Wegelt L, FordHutchinson AW, Tagari P. Increased urinary leukotriene excretion in patients with cardiac ischaemia: in vivo evidence for 5-lipoxygenase activation. Circulation 1992;85: 230-6.

29. Yang Z, Richard V, von Segesser L, et al. Threshold concentrations of endothelin-1 potentiate constrictions to norepinephrine and serotonin in human arteries: a new mechanism of vasospasm? Circulation 1990;82:188-95.

30. Nakaki T, Nakayama M, Yamamoto S, Kato R. Endothelin-mediated stimulation of DNA synthesis in vascular smooth muscle cells. Biochem Biophys Res Commun 1989;158:880-3.

31. Chester AH, Martin GR, Bodelsson M, et al. 5-hydroxytryptamine receptor profile in healthy and diseased human epicardial coronary arteries. Cardiovasc Res 1990;24: 932-7.

32. Aston JH, Ogletree ML, Michel IM, et al. Cooperative mediation by serotonin $S_{2}$ and thromboxane $A_{2}$ /prostaglandin $\mathrm{H}_{2}$ receptor activation of cyclic flow variations in dogs with severe coronary artery stenoses. Circulation 1987;76:952-9. 